\title{
The relationship between scapular endurance and core endurance in elite amputee football players
}

\author{
Gurkan Gunaydin
}

Department of Physical Therapy and Rehabilitation, Faculty of Health Sciences, Aydn Adnan Menderes University, Efeler, Aydın, Turkey

\section{abstract}

Background: Body structure constitutes a kinetic chain with thoracolumbar fascia and this chain may induce a relationship between scapular and spinal stabilizers. Amputee soccer players use crutches during the game and, considering that the crutch use may also activate different muscle groups, the possibility of the relationship between scapular and spinal stabilizers becomes important for organizing training programs. The aim of this study is to determine the relationship between scapular endurance and core endurance in elite amputee players.

Material and methods:

Fifteen male amputee national football team players took part in the study. The players' scapular endurance was evaluated by a dynamometer, and the modified side bridge test was used to evaluate core endurance.

Results: The relationship between scapular and core endurance was investigated via the Linear Regression Model. The analysis revealed a positive association between scapular endurance and core endurance (B: 0.501 , B: 0.561, p: 0.029).

Conclusions: This study shows the relationship between scapular and core endurance in amputee football players. Given the assumptions about scapular and core endurance weakness, including scapular muscle exercises along with core exercises in the training programs might be useful for improving performance.

Key words: soccer, amputees; athletes, crutches, exercise.

\section{article details}

Article statistics:

Full-text PDF:

Copyright

Indexation:

Funding:

Conflict of interests:

Corresponding author:

Open Access License:

Word count: 2,888; Tables: 3; Figures: 1; References: 35

Received: November 2020; Accepted: February 2021; Published: March 2021

http://www.balticsportscience.com

(c) Gdansk University of Physical Education and Sport, Poland

Celdes, Clarivate Analytics Emerging Sources Citation Index (ESCI), CNKI Scholar (China National Knowledge Infrastructure), CNPIEC, DOAJ, EBSCO - Central \& Eastern European Academic Source, EBSCO - SPORTDiscus, EBSCO Discovery Service, Google Scholar, Index Copernicus, J-Gate, Naviga (Softweco, Primo Central (ExLibris), ProQuest - Family Health, ProQuest - Health \& Medical Complete, ProQuest - Illustrata: Health Sciences, ProQuest Nursing \& Allied Health Source, Summon (Serials Solutions/ProQuest, TDOne (TDNet), Ulrich's Periodicals Directory/ ulrichsweb, WorldCat (OCLC)

This research received no specific grant from any funding agency in the public, commercial, or not-for-profit sectors. Author has declared that no competing interest exists.

Gurkan Gunaydin, Department of Physical Therapy and Rehabilitation, Faculty of Health Sciences, Aydn Adnan Menderes University, Efeler, Aydın, Turkey; Phone: +90 55472427 42; E-mail: gunaydingrkn@gmail.com; https://orcid.org/0000-0003-3432-6431

This is an open access article distributed under the terms of the Creative Commons Attribution-Non-Commercial-NoDerivatives 4.0 International (https://creativecommons.org/licenses/by-nc-nd/4.0/), which permits use, distribution and reproduction in any medium, provided the original work is properly cited, the use is non-commercial and is otherwise in compliance with the license. 


\section{INTRODUCTION}

Football is a sport which is followed with great interest around the world, and almost everyone agrees on its popularity. This interest in football has attracted not only healthy athletes but also individuals with different disabilities [1]. One of the variations of football created by this passion is amputee football, which has been continuously increasing its prevalence since its beginnings [2]. Amputee football, also known as amputee soccer, is played with two teams of seven players (one goalkeeper, six players) in two periods of 25 minutes each. The pitch dimensions are $40 \times 60$ meters in amputee football, and while there is upper extremity amputation in goalkeepers, there is lower extremity amputation in players. The use of the prosthesis during the game is not permitted, and players use crutches for upper body weight transfer and functional movements [3]. Crutches are adjustable and bilaterally held. Using crutches helps the players perform functional activities on the pitch and maintain balance when kicking the ball [3]. Although game rules and pitch dimensions differ from normal football, it is necessary to have a high level of endurance, strength, flexibility, coordination, balance, and spinal stabilization in amputee football [3-5].

The body structure is thought to be a kinetic chain, and muscle groups are thought to play important roles in this kinetic chain. This approach suggests that there may be a relationship between core stabilization, strength, and endurance [4, 6, 7]. Core muscles include various muscle groups that stabilize the shoulder band, the pelvis, and the spine, and they serve as the pivot for extremity movements [8]. It is known that the core muscles stabilize the lumbar region and core stabilization affects muscle activation [9]. The structure that plays a possible role in this interaction is the thoracolumbar fascia [10]. This fascia has an important function in the load and energy transfer between the upper and lower extremities [11]. Thoracolumbar fascia derives from the aponeurosis of latissimus dorsi, and with the fascial cover it forms, it passes through the pectoralis major, pectoralis minor, trapezius and serratus anterior, and extends to the sacrum and gluteus maximus [12]. This suggests that there may be a relationship between core stabilizers and scapular stabilizers [13]. Amputee football is a branch of sport with success-oriented investments, and it has gradually commenced to professionalize although it is not a Paralympic Branch. However, there are few studies on amputee football. Determining the strength, endurance and performance relationship levels of the players with new studies may help to organize training programs and increase sport performance. From another point of view, amputee football is played with crutches, and it is known that the use of crutches may activate different muscle groups and biomechanical mechanisms [14]. Considering the relationship between core stabilization, sportive performance, and risk of injury [4], it is assumed that the level of a possible relationship between scapular endurance and core endurance in amputee players may reveal important clinical output. Therefore, the aim of this study was to determine the relationship between scapular endurance and core endurance in elite amputee football players, and it was hypothesized that there would be a statistically significant relationship between these parameters.

\section{MATERIAL AND METHODS}

This study was performed as a cross-sectional study design. Ethical approval was taken from Aydn Adnan Menderes University Non-Interventional Clinical Research Ethics Board (Date: 01.08.2018, Number: 92340882-050.04.04 and protocol number 2018/41) and from the Board of Health of the Turkish Sports Federation for the Physically Disabled. Written informed consent was also obtained from all the participants. The players who volunteered to participate in the study and who were aged over 18 years were included in this scientific research, while the players with upper extremity amputation and those who have undergone surgery in the upper or lower extremities within the last 6 months were 
excluded from the study. Ultimately, 15 players of the Turkish National Male Amputee Football Team participated in the study. Of the 15 players, nine had the left and six had the right lower extremity amputation and three had above knee, three had knee disarticulation and the nine had below knee amputation.

The same physiotherapist made all the evaluations and collected all the demographic data, and a rest period of 5 minutes was allowed between the evaluations [4]. For the endurance tests, two trials were performed and the best result was chosen for the analysis [15]. Prior to the evaluations, the players did warm-up activities with the National Team coach. For warm-up, subjects were jogging for 5 minutes. Then, static and dynamic stretching exercises for the upper and lower extremities and static stretching exercises for the trunk muscles were applied with 10 repetitions approximately for 5 minutes.

\section{Scapular endurance test}

Scapular muscle endurance was measured with a dynamometer (Feta ${ }^{\circledR}$ F0202 1 KG/10 $\mathrm{N}$ capacity/Turkey). The participants took a sitting position before starting the test. Then, when the shoulders and elbows were at 90 degrees of flexion and both scapula were in the neutral position, a suitable bar chosen among 10 bars of different sizes $(18-36 \mathrm{~cm})$ was placed between the elbows. The participants held the dynamometer between their hands and performed shoulder external rotation until the dynamometer showed $1 \mathrm{~kg}$ load capacity (Figure 1). The test was terminated when the participant could not maintain resistance, dropped the bar, or distorted the 90-degree flexion angle. The test time was recorded in seconds for each participant $[13,16]$.

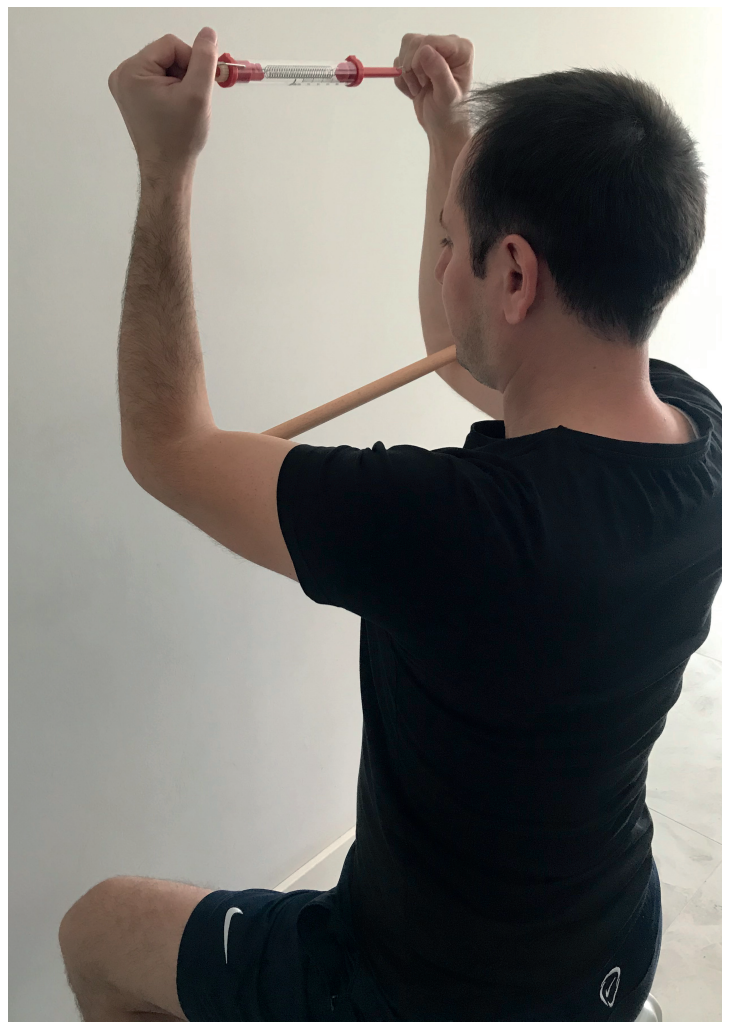

Fig. 1. Scapular endurance test

\section{Core endurance test}

The modified side bridge test was used to determine core endurance. The participants lay on the bed in a way to keep their amputated sides at the top and to put their weights 
on their arms by bending their elbow underneath. In the meantime, the players extended the arm at the top toward their amputated extremities. Then, the participants raised their body up and maintained a straight position. The test time was recorded in seconds for each participant $[4,17]$.

\section{Statistical analysis}

Normality analyses of the data were tested using visual (histogram, probability plots) and analytical (Shapiro Wilk's test) methods, and it was seen that the variables were not normally distributed, so the logarithmic transformation was performed for the analysis [18]. The relationship between scapular endurance and core endurance was determined with Linear Regression Analysis, and the statistical significance level was determined as $\mathrm{p}<0.05$ for all the data.

\section{RESULTS}

The mean age of the 15 National Team players participating in the study was $26.73 \pm 5.43$ years. Eight of these amputations were congenital, and seven of them were acquired. When the players were examined in terms of football zones, six players were in the defense, six players were in the midfield, and three players were in the offensive zone. The demographic data, such as age, height and weight of 15 National Team players in the study were summarized in Table 1.

The regression analysis revealed that there was a statistically significant and positive association between scapular endurance and core endurance (B: 0.501, $\beta$ : 0.561, p: 0.029). Table 2 and Table 3 show details of the endurance tests and the regression analyses, respectively.

Table 1. Demographics of the amputee players

\begin{tabular}{lcc} 
& Mean \pm SD & Median (Minimum-Maximum) \\
\hline Age (year) & $26.73 \pm 5.43$ & $28.00(18-40)$ \\
Height $(\mathrm{cm})$ & $174.93 \pm 5.13$ & $176.00(165.00-183.00)$ \\
Weight $(\mathrm{kg})$ & $66.40 \pm 6.90$ & $66.30(54.60-77.20)$ \\
Sports experience (year) & $8.33 \pm 1.88$ & $8.00(5.00-12.00)$ \\
\hline
\end{tabular}

Table 2. Mean and median values of the endurances

\begin{tabular}{lcc} 
& Mean \pm SD & Median (Minimum-Maximum) \\
\hline Scapular endurance & $59.60 \pm 24.21 \mathrm{~s}$ & $56.70 \mathrm{~s}(27.53-119.98)$ \\
Core endurance & $100.64 \pm 27.44 \mathrm{~s}$ & $118.32 \mathrm{~s}(42.99-120)$ \\
\hline
\end{tabular}

Table 3. Linear regression of the scapular and core endurance

\begin{tabular}{cccccccccc} 
DV & IV & $\mathrm{R}^{2}$ & $\mathrm{R}$ & $\mathrm{B}$ & $\beta$ & $95 \% \mathrm{Cl}$ & $\mathrm{t}$ & $\mathrm{F}$ & $\mathrm{p}$ \\
\hline $\mathrm{CE}$ & $\mathrm{SE}$ & 0.315 & 0.561 & 0.501 & 0.561 & $(0.059-0.943)$ & 2.446 & 5.984 & 0.029 \\
\hline
\end{tabular}

DV: Dependent variable, IV: Independent variable, CE: Core endurance, SE: Scapular endurance, B: unstandardized regression model, $\beta$ : standardized coefficient.

\section{DISCUSSION}

Disabled sports are important not only for health promotion and disease prevention but also for social participation of the disabled individuals. For this reason, sport activities are highly encouraged for people with disabilities [19]. Amputee football, one of these 
sports activities, has been increasing its popularity since the day it was founded, and better performance skills are expected in the game as it becomes more professional [2]. There is limited literature on amputee football and new studies may help determine the players' physical fitness. Besides, they may reveal a relationship between strength and endurance, increase the health levels and improve the performance skills of the players. Therefore, this study examined the relationship between scapular endurance and core endurance of the elite amputee players. The study suggests a significant association between scapular muscle endurance and the modified side bridge test, and the hypothesis is accepted. Hazar et al. investigated the relationship between scapular endurance and core endurance in healthy adults and reported a positive weak relationship [13]. However, their study consisted of healthy individuals and the participants' physical activity levels were low. These are considered as the limitations of the study. Although the results of Hazar et al.'s study and this study support each other, the study populations are different from one another. There are no other studies investigating the relationship between scapular endurance and core endurance in the literature.

Amputee football, whose players have one amputated extremity, requires endurance, flexibility, speed, strength, stabilization, sportive performance, and high level of control [2, 5]. Players use crutches because of their missing extremities. During the use of crutches, many different muscle groups work, and it is expected that strength and endurance in these muscle groups should be adequate to reduce the risk of injury and increase performance $[4,20]$. The fact that this study was performed with a group of athletes with strong scapular and core stabilizers may help both to produce a clinical output and to provide a more clear interpretation of the results. As this study includes the amputee players who are expected to have higher scapular stabilization due to both being athletes and using crutches, it differs from Hazar et al.'s study [13], which is the only study in the literature.

It has been reported in many studies that core stabilization reduces the risk of injury and may have positive effects on performance [4, 21]. Adequate core stabilization reduces the strain on the joints with proper body biomechanics, allowing the athlete to produce maximum power [22]. For this reason, coaches frequently include core stabilization exercises in their training programs. Considering that the body is composed of a kinetic chain, the thoracolumbar fascia plays an important role in the attachment of the upper and lower body parts [11]. The thoracolumbar fascia starts from aponeurosis of the latissimus dorsi, extending to the sacrum and gluteus maximus, including the deep back and trunk muscles and the multifidus [6]. The thoracolumbar fascia is also associated with the internal oblique and transversus abdominis muscles, providing three-dimensional support and core stabilization of the spine [23]. Given this information, the connection of the thoracolumbar fascia and the kinetic chain may explain the interaction between scapular endurance and core endurance in this study. Activation of transversus abdominis results in increased intraabdominal pressure and thoracolumbar fascia tension [6]. The fascia extending to the scapular muscles through the latissimus dorsi with increasing tension may thus have interacted with the scapular muscles. In this view, another important point is the latissimus dorsi muscle. Unlike normal football mechanics, the use of crutches in amputee football reveals the importance of the latissimus dorsi muscle. In a study examining upper extremity kinetic changes with the use of crutches, at the end of the crutch swing phase, approximately 10 degrees of abduction and 20 degrees of flexion angle have been shown to move to 0 degrees of adduction and extension at the beginning of the crutch swing phase and have a humeral internal rotation of 15-25 degrees during the gait phase [14]. When this mechanic is considered as a complete pattern, the gait phase with the crutches includes adduction, extension and internal rotation component, which means latissimus dorsi activation. Other EMG supported studies also highlight the importance of thoracohumeral muscle activation during the use of the crutches in amputated individuals 
$[24,25]$. The latissimus dorsi muscle, which may be more active due to crutch use in amputee football, may have made the interaction between scapular and core endurance more important and prominent with the connection of the thoracolumbar fascia. According to the possible results from all these information, considering the relationship between core stabilization and injury risk and performance, scapular strengthening may play an important role in increasing performance dynamics in amputee players. Furthermore, the inclusion of latissimus dorsi strengthening exercises in the training programs, which is involved in the interaction of scapular and core group muscles, may be beneficial in terms of performance changes although it is beyond the scope of this study.

Muscle imbalances and balance changes seen as a result of amputation, reveal many compensation mechanisms. Although amputee football players have similar requirements, there are many dynamics different from regular football. Rise of the amputation level in players leads to some negative biomechanical changes. Examples include increased energy consumption per unit time [26], limitation of hip extension range of motion, increased severity of low back pain [27, 28], and increased loss of lower extremity strength [29]. However, to what extent the changes in amputation level of amputee soccer players had an effect on performance differences could not be clearly explained. Furthermore, the fact that the multifidus muscle is more powerful in trans-femoral amputees compared to trans-tibial amputees [28] complicates this situation. Since amputee football has many different dynamics, further studies are needed to examine the effect of the amputation level on performance changes of the players.

According to the literature review, this is the first study to measure the scapular endurance in disabled individuals. As a result of this study, scapular endurance accounted to $59.60 \pm 24.21 \mathrm{~s}$ in elite amputee players. In their study, Hazar et al. calculated the scapular endurance to be 37.19 $\pm 23.28 \mathrm{~s}$ in healthy participants [13], and Eraslan et al. determined as $61.49 \pm 27.63 \mathrm{~s}$ in textile workers [30]. When these results are compared, it is observed that the scapular endurance of the amputee players is higher than that of Hazar et al. population, and is similar to that of Eraslan et al. population. One of the possible reasons for this situation is the sedentary individual population of the Hazar et al. study. In Eraslan's study, it is easy to see that the study population consists of textile workers with intense working periods. Considering textile workers, their high scapular muscle activation may be due to their profession. It seems meaningful to have similar endurance results with amputee players who are another group with high scapular muscle activation. As a result of this study, the core endurance of amputee players was found to be $100.64 \pm 27.44 \mathrm{~s}$. In their study, Hazar et al. calculated the core endurance at $33.93 \pm 15.05 \mathrm{~s}$ in healthy participants [13], and Sandrey et al. determined it as 77.20 $\pm 34.28 \mathrm{~s}$ in high school athletes [31]. The obtained high levels of core endurance values were similar to the scapular endurance results according to the Hazar et al. study. A comparison of the population of athletes and sedentary individuals may reveal these results. The interesting situation is the difference between amputee players' and the high school athletes' core endurance levels. There may be two possible explanations for this status. The first one is that in both studies the compared groups consisted of athletes, but in this study the athletes were elite players categorized at the national team level. The second reason may be due to a more complex mechanism. It is known that amputation exerts increased force on the intact limb, changes body biomechanics and disrupts the strength balance [32]. In this mechanism, primarily weak hip extensors, knee extensors and hip abductors are encountered [27-29]. With the occurrence of hip muscle weakness, psoas major is shortened and hip extension is limited in the amputated extremity [33]. Increased hip flexor moment increases anterior pelvic tilts and thus increases lumbar lordosis and disrupts spinal mechanism [34]. As a result, amputated individuals should have stronger back extensor strength in order to tolerate weak hip and knee extensor muscles and changing center of gravity $[27,28]$. The 
study also showed that increased back extensor strength was encountered with rising amputation level [28]. This compensation mechanism may have produced a higher level of core endurance in amputated players.

In this study, the upper extremity dynamometer and the modified side bridge test were used to determine scapular endurance and core endurance, respectively. All the tests used in this study are easy to use, valid, and reliable [4, 16, 35]. However, when performing the modified side bridge test, the majority of the body weight is carried by the upper extremity and the scapular muscles due to the structure of the test. Therefore, the significant association between scapular and core endurance may be because both tests are related to the upper extremity. The use of only the side bridge test to determine core endurance is considered to be a limitation of this study. The other limitation is the small sample size and narrow population of the study due to the capacity of the national team. It should be noted that these results reflect only amputee football players' conditions. To implement these results on non-football-playing amputees who also use crutches, future studies should be performed with related population as well.

\section{CONCLUSION}

The mechanism of the amputee football has not been fully revealed due to the limited number of studies in the newly developed sport. In this study, it is important to show the association between scapular and core endurance levels in amputee football players. Considering the risk of loss of performance and injury that may arise in the absence of core strength, it is considered beneficial to add scapular strengthening to training programs in addition to core stabilization training in amputee footballers in order to increase sporting performance. Besides, determining the relationship between different endurance levels and performance and injury risk in amputee players with future studies might help to clarify the mechanism of amputee football.

\section{ACKNOWLEDGEMENTS}

The author would like to extend their gratitude to the Board of Health of Turkish Sports Federation for the Physically Disabled and to the esteemed players and coaches of the Turkish Amputee National Football Team for their support in conducting this study.

\section{REFERENCES}

[1] Simim, MA, da Mota GR, Marocolo M, da Silva BV, de Mello MT, Bradley PS. The demands of amputee soccer impair muscular endurance and power indices but not match physical performance. Adapt Phys Act Q. 2018;35:76-92. https://doi.org/10.1123/apaq.2016-0147

[2] Özkan A, Safaz I, Safaz İ, Yaşar E, Yazıcıoğlu, K. An examination of physical fitness related with performance characteristics of amputee football players. IntJSCS. 2014;1:66-77.

[3] Yazicioglu K, Taskaynatan MA, Guzelkucuk U, Tugcu I. Effect of playing football (soccer) on balance, strength, and quality of life in unilateral below-knee amputees. Am J Phys Med Rehabil. 2007;86:800-805. https://doi.org/10.1097/ PHM.0b013e318151fc74

[4] Aytar A, Pekyavas NO, Ergun N, Karatas M. Is there a relationship between core stability, balance and strength in amputee soccer players? A pilot study. Prosthet Orthot Int. 2012;36:332-338. https://doi.org/10.1177/0309364612445836

[5] Lowther J, Lane A, Lane H. Self-efficacy and psychological skills during the amputee soccer world cup. Athl Insight 2002;4:23-34.

[6] Kibler WB, Press J, Sciascia A. The role of core stability in athletic function. Sports Med. 2006;36:189-198. https:// doi.org/10.2165/00007256-200636030-00001

[7] Moirenfeld I, Ayalon M, Ben-Sira D, Isakov E. Isokinetic strength and endurance of the knee extensors and flexors in transtibial amputees. Prosthet Orthot Int. 2000;24:221-225. https://doi.org/10.1080/03093640008726551

[8] Barati A, Safarcherati A, Aghayari A, Azizi F, Abbasi H. Evaluation of relationship between trunk muscle endurance and static balance in male students. AsJSM. 2013;4:289-294. https://doi.org/10.5812/asjsm.34250

[9] Cho JY, Shim JH, Choi HY, Song KM, Moon SI, Seo, KT. The effects of core stability exercise using an ultrasound imaging system on muscle activation of shoulder region. JDCTA. 2013;7:375. https://doi.org/10.4156/jdcta.vol7.issue11.48

[10] Kisner C, Colby LA, Borstad J. Therapeutic exercise: Foundations and techniques. Fa Davis, 2017. 
[11] Vleeming A, Schuenke M, Danneels L, Willard F. The functional coupling of the deep abdominal and paraspinal muscles: the effects of simulated paraspinal muscle contraction on force transfer to the middle and posterior layer of the thoracolumbar fascia. J Anat. 2014;225:447-462. https://doi.org/10.1111/joa.12227

[12] Willard F, Vleeming A, Schuenke M, Danneels L, Schleip R. The thoracolumbar fascia: anatomy, function and clinical considerations. J Anat. 2012;221:507-536. https://doi.org/10.1111/j.1469-7580.2012.01511.x

[13] Hazar Kanik, Z, Pala OO, Gunaydin G, Sozlu U, Alkan ZB, Basar S, Citaker, S. Relationship between scapular muscle and core endurance in healthy subjects. J Back Musculoskelet Rehabil. 2017;30:811-817. https://doi.org/10.3233/ BMR-150497

[14] Requejo PS, Wahl DP, Bontrager EL, Newsam CJ, Gronley JK, Mulroy SJ, Perry J. Upper extremity kinetics during Lofstrand crutch-assisted gait. Med Eng Phys. 2005;27:19-29. https://doi.org/10.1016/j.medengphy.2004.08.008

[15] Okada T, Huxel KC, Nesser TW. Relationship between core stability, functional movement, and performance. J Strength Cond Res. 2011;25:252-61. https://doi.org/10.1519/JSC.0b013e3181b22b3e

[16] Edmondston SJ, Wallumrød ME, MacLéid F, Kvamme LS, Joebges S, Brabham GC. Reliability of isometric muscle endurance tests in subjects with postural neck pain. J Manipulative Physiol Ther. 2008;31:348-354. https://doi. org/10.1016/j.jmpt.2008.04.010

[17] Huxel Bliven KC, Anderson BE. Core stability training for injury prevention. Sports Health. 2013;5:514-522. https:// doi.org/10.1177/1941738113481200

[18] Alwerdt J, Valdés EG, Chanti-Ketterl M, Small BJ, Edwards JD. The relationship between phytoestrogens and speed of processing. Menopause. 2016;23:911-918. https://doi.org/10.1097/GME.0000000000000632

[19] Mikami Y, Fukuhara K, Kawae T, et al. Exercise loading for cardiopulmonary assessment and evaluation of endurance in amputee football players. J Phys Ther Sci. 2018;30:960-965. https://doi.org/10.1589/jpts.30.960

[20] Tatar Y, Gercek N, Ramazanoglu N, et al. Load distribution on the foot and Lofstrand Crutches of amputee football players. Gait Posture. 2018;64:169-173. https://doi.org/10.1016/j.gaitpost.2018.06.008

[21] Sato K, Mokha M. Does core strength training influence running kinetics, lower-extremity stability, and 5000-M performance in runners? J Strength Cond Res. 2009;23:133-140. https://doi.org/10.1519/JSC.0b013e31818eb0c5

[22] Abdelraouf OR, Abdel-aziem AA. The relationship between core endurance and back dysfunction in collegiate male athletes with and without nonspecific low back pain. Int J Sports Phys Ther. 2016;11:337-344.

[23] Young JL, Herring SA, Press JM, Casazza BA. The influence of the spine on the shoulder in the throwing athlete. J Back Musculoskelet Rehabil. 1996;7:5-17. https://doi.org/10.3233/BMR-1996-7103

[24] Mulroy SJ, Hatchett P, Eberly VJ, Lighthall Haubert L, Conners S, Requejo PS. Shoulder strength and physical activity predictors of shoulder pain in people with paraplegia from spinal injury: prospective cohort study. Phys Ther. 2015;95:1027-1038. https://doi.org/10.2522/ptj.20130606

[25] Newsam CJ, Lee AD, Mulroy SJ, Perry J. Shoulder EMG during depression raise in men with spinal cord injury: the influence of lesion level. J Spinal Cord Med. 2003;26:59-64. https://doi.org/10.1080/10790268.2003.11753662

[26] Waters RL, Mulroy S. The energy expenditure of normal and pathologic gait. Gait Posture. 1999;9:207-231. https:// doi.org/10.1016/S0966-6362(99)00009-0

[27] Devan H, Hendrick P, Ribeiro DC, Hale LA, Carman A. Asymmetrical movements of the lumbopelvic region: is this a potential mechanism for low back pain in people with lower limb amputation? Med Hypotheses. 2014;82:77-85. https://doi.org/10.1016/j.mehy.2013.11.012

[28] Friel K, Domholdt E, Smith DG. Physical and functional measures related to low back pain in individuals with lower-limb amputation: an exploratory pilot study. J Rehabil Res Dev. 2005;42:155-166. https://doi.org/10.1682/ JRRD.2004.08.0090

[29] Jaegers SM, Arendzen JH, de Jongh HJ. Prosthetic gait of unilateral transfemoral amputees: A kinematic study. Arch Phys Med Rehabil. 1995;76:736-743. https://doi.org/10.1016/S0003-9993(95)80528-1

[30] Eraslan U, Gelecek N, Genc A. Effect of scapular muscle endurance on chronic shoulder pain in textile workers. J Back Musculoskelet Rehabil. 2013:26;25-31. https://doi.org/10.3233/BMR-2012-0346

[31] Sandrey MA, Mitzel JG. Improvement in dynamic balance and core endurance after a 6-week core-stability-training program in high school track and field athletes. J Sport Rehabil. 2013;22:264-271. https://doi.org/10.1123/jsr.22.4.264

[32] Gailey R, Allen K, Castles J, Kucharik J, Roeder M. Review of secondary physical conditions associated with lower-limb amputation and long-term prosthesis use. J Rehabil Res Dev. 2008;45:15-29. https://doi.org/10.1682/ JRRD.2006.11.0147

[33] Bogduk NPMHG, Pearcy M, Hadfield G. Anatomy and biomechanics of psoas major. Clin Biomech. 1992;7:109-119. https://doi.org/10.1016/0268-0033(92)90024-X

[34] Ehde DM, Smith DG, Czerniecki JM, Campbell KM, Malchow DM, Robinson LR. Back pain as a secondary disability in persons with lower limb amputations. Arch Phys Med Rehabil. 2001;82:731-734. https://doi.org/10.1053/ apmr.2001.21962

[35] Evans K, Refshauge KM, Adams R. Trunk muscle endurance tests: reliability, and gender differences in athletes. J Sci Med Sport. 2007;10:447-455. https://doi.org/10.1016/j.jsams.2006.09.003 